\title{
STIMULATION OF PROTEIN SYNTHESIS AND GLUCOSE UTILIZATION IN THE HYPOGLOSSAL NUCLEUS INDUCED BY AXOTOMY
}

\author{
CAROLYN B. SMITH, ${ }^{1}$ ALISON M. CRANE, MASSAKO KADEKARO, BERNARD W. AGRANOFF, ${ }^{*}$ \\ AND LOUIS SOKOLOFF
}
Laboratory of Cerebral Metabolism, National Institute of Mental Health, United States Public Health Service, Department of Health and Human Services, Bethesda, Maryland 20205 and ${ }^{*}$ Mental Health Research Institute, Neuroscience Laboratory Building, University of Michigan, Ann Arbor, Michigan 48109

Received January 10, 1984; Revised March 19, 1984; Accepted April 18, 1984

\begin{abstract}
The metabolic responses of rat hypoglossal nuclei to unilateral section of the 12 th cranial nerve have been studied. Changes in the rates of protein synthesis and glucose utilization in the regenerating nucleus were determined with two quantitative autoradiographic techniques, the $\mathrm{L}-\left[1-{ }^{14} \mathrm{C}\right]$ leucine method and the $\left[{ }^{14} \mathrm{C}\right]$ deoxyglucose method, respectively. The results show that both of these processes increase in the nucleus ipsilateral to the sectioned nerve and are unaffected in the contralateral nucleus as compared with shamoperated animals. The time courses of these metabolic changes have been compared with that of the return of functional innervation of the tongue. An increase in glucose utilization is first detected $24 \mathrm{hr}$ postaxotomy. It is maximal between 1 and 3 days postaxotomy and constitutes an $84 \%$ increase over the rate in the contralateral control nucleus. The increase in protein synthesis is of smaller magnitude than that of glucose utilization. It is maximal at $48 \mathrm{hr}$ after axotomy and constitutes a $25 \%$ increase over the rate in the contralateral nucleus. The increases in both of these metabolic processes persist even after functional recovery of the tongue at 21 days postaxotomy. Protein synthesis and glucose utilization return to normal levels between 24 and 35 days postaxotomy. Although the time courses of the changes in protein synthesis and glucose utilization are similar, the magnitude of the increase in glucose utilization is too large to be accounted for by the energy requirements of the relatively small increase in protein synthesis and probably reflects other processes as well, including altered function of the soma-dendritic membrane of regenerating neurons.
\end{abstract}

Axonal section or injury leads to characteristic metabolic and morphological changes in the cell bodies of origin. The changes are usually followed by regeneration of the axons and restoration of function if the nerve process is outside the CNS. The morphological changes first described by Nissl (1892) include perikaryal swelling, displacement of the nucleus from its usually central position to one of eccentricity, increases in size in both the nucleus and the nucleolus, and loss of basophilia, now known to reflect disorganization of the ordered arrays of rough endoplasmic reticulum (Lieberman, 1971). Studies with radiolabeled precursors have shown that changes in nucleic acid and protein synthesis occur in regenerating neurons and their surrounding glial cells. For example, there is increased uptake of $\left[{ }^{3} \mathrm{H}\right]$ thymidine into glial cells surrounding neurons undergoing regeneration (Watson, 1965), which probably reflects glial cell proliferation. Similarly, increases have been found in the uptake of $\left[{ }^{3} \mathrm{H}\right]$ uridine and $\left[{ }^{3} \mathrm{H}\right]$ orotic acid into regenerating neurons, which suggest that RNA synthesis may be increased (Watson, 1965; Murray, 1973). Increased synthesis of RNA would be expected to presage an increase in protein synthesis. However, there have been conflicting reports on changes in the incorporation of radiolabeled amino acids into protein in regenerating neurons. Both increases (Brattgard et

\footnotetext{
${ }^{1}$ To whom correspondence should be addressed.
}

al., 1958; Watson, 1965) and decreases (Engh et al., 1971) in incorporation of amino acids have been reported. It has also been observed that there is decreased neuronal content of specific proteins, particularly those associated with neurotransmitter functions. For example, in regenerating noradrenergic neurons, tyrosine hydroxylase, dopamine $\beta$-hydroxylase, and monoamine oxidase (Cheah and Geffen, 1973) are reduced whereas in cholinergic neurons, cholinesterase (Watson, 1966) and choline acetyltransferase (Hebb and Waites, 1956) are reduced. In general, there may be a shift away from synthesis of materials required for neurotransmission and toward the production of structural proteins such as tubulin (Heacock and Agranoff, 1976).

Energy metabolism also increases in regenerating neurons. The rate of glucose utilization increases in the rat hypoglossal nucleus following unilateral axotomy (Agranoff et al., 1980; Kreutzberg and Emmert, 1980; Singer and Mehler, 1980). The increase occurs early and is of sufficient magnitude to be visualized on the autoradiographic images produced by the $\left[{ }^{14} \mathrm{C}\right]$ deoxyglucose method. Increases have also been observed in the activities of enzymes of the pentose phosphate shunt pathway in regenerating autonomic ganglia (Härkönen and Kaufman, 1974). The factors involved in the enhanced glucose consumption are not known, but it has been suggested that increased synthetic activity may play an important role. 
In the present studies the time courses of the effects of axotomy on glucose utilization and protein synthesis in the hypoglossal nucleus have been examined. Two quantitative autoradiographic methods have been used: the $2-\left[{ }^{14} \mathrm{C}\right]$ deoxyglucose method for the determination of local rates of glucose consumption and the $\left[1-{ }^{14} \mathrm{C}\right]$ leucine method for the determination of local rates of protein synthesis. With these methods, rates of both glucose consumption and protein synthesis have been compared. In addition, the time course of the return of function of the tongue has been determined and compared with the time courses and magnitudes of the metabolic changes.

\section{Materials and Methods}

\section{Animals}

Adult, female Sprague-Dawley rats ( 160 to $250 \mathrm{gm}$ ) were anesthetized with ketamine $(200 \mathrm{mg} / \mathrm{kg})$, which was administered intramuscularly. The hypoglossal nerve on one side was cut at the level of the anterior belly of the digastric muscle. A 3- to 4-mm segment of the nerve was removed to ensure that the cut was complete. Sham-operated animals were prepared by unilateral exposure of the hypoglossal nerve. Following the surgery, animals were returned to their cages and allowed to recover. They were maintained on Purina Laboratory Chow and water ad libitum until $14 \mathrm{hr}$ before the measurement of protein synthesis or glucose utilization, at which time they were deprived of food. The physiological state of the animals at the time of the measurements of the metabolic processes was assessed by monitoring of rectal temperature, mean arterial blood pressure, hematocrit, and arterial blood $\mathrm{pH}$, $\mathrm{pCO}_{2}$ and $\mathrm{pO}_{2}$. Only animals with values for these variables within the normal range (Sokoloff et al., 1977) were included in these studies.

\section{Determination of regional rates of protein synthesis}

Theory. Local rates of protein synthesis were determined by means of a recently developed autoradiographic method (Smith ct al., 1980). This method is based on the use of $\mathrm{L}-\left[1-{ }^{14} \mathrm{C}\right]$ leucine as a tracer to measure leucine incorporation into protein. Carboxyl-labeled leucine has been chosen as the tracer because the only pathway for the metabolic degradation of leucine entails a transamination followed by decarboxylation. Therefore, in the metabolism of $\mathrm{L}-\left[1-{ }^{14} \mathrm{C}\right]$ leucine the label is transiently transferred to $\alpha$-ketoisocaproic acid and ultimately to ${ }^{14} \mathrm{CO}_{2}$, which is negligibly reincorporated because of dilution by the large amount of unlabeled $\mathrm{CO}_{2}$ produced by cerebral carbohydrate metabolism (Banker and Cotman, 1971). There are, therefore, no residual radioactive products other than the labeled protein.

A model (Fig. 1A) has been designed based on the following assumptions and requirements: (1) tracer kinetics; (2) a single homogeneous tissue compartment; (3) a steady state for protein and amino acid metabolism; (4) negligible breakdown of the labeled protein during the experimental period; and (5) no significant dilution of the tracer by unlabeled L-leucine derived from steady-state protein degradation. By mathematical analysis of the kinetics of exchange of leucine between plasma and tissue, its metabolic degradation, and its incorporation into protein, an equation (Fig. $1 B$ ) has been derived that defines the rate of L-leucine incorporation into protein in terms of the time course of the plasma specific activity, the final tissue concentration of ${ }^{14} \mathrm{C}$, and experimentally determined rate constants.

The rate constants, $k_{1},\left(k_{2}+k_{3}\right)$, and $k_{4}$ (all defined in Fig. 1), were determined in a separate group of 15 animals matched for age, sex, and weight. The animals were administered $40 \mu \mathrm{Ci}$ of $\mathrm{L}-\left[1-{ }^{14} \mathrm{C}\right]$ leucine intravenously and were killed after $5,10,15,20$, and $25 \mathrm{~min}$. The animals killed at $5 \mathrm{~min}$ were given a constant infusion of the tracer. All of the other animals were given the tracer as a bolus injection. Three animals were studied for each time period. Timed arterial blood samples were drawn during the experiment and assayed for the time course of the plasma $\left[{ }^{14} \mathrm{C}\right]$ leucine concentration prior to the time of killing. Regional brain ${ }^{14} \mathrm{C}$ concentrations were determined by quantitative autoradiography. The following equation was then fitted to the tissue ${ }^{14} \mathrm{C}$ concentrations (i.e., $C_{i}^{*}$ ) at the time of killing and the time courses of the plasma $\left[{ }^{14} \mathrm{C}\right]$ leucine concentration (i.e., $\mathrm{C}_{p}^{*}$ ) obtained from all of the rats:

$$
\begin{aligned}
C_{i}^{*}(\tau)=k_{1} e^{-\left(k_{2}+k_{3}+k_{4}\right) \tau} & \int_{0}^{\tau} C_{p}^{*} e^{\left(k_{2}+k_{3}+k_{4}\right) t} d t \\
& +k_{1} k_{4} \int_{0}^{\tau}\left[e^{-\left(k_{2}+k_{3}+k_{4}\right) T} \int_{0}^{T} C_{p}^{*} e^{\left(k_{2}+k_{3}+k_{4}\right) t} d t\right] d T
\end{aligned}
$$

This equation defines the total tissue ${ }^{14} \mathrm{C}$ concentrations as a function of time in terms of the history of the plasma $\left[{ }^{14} \mathrm{C}\right]$ leucine concentration from zero time to any given time, $\tau$, and the rate constants, $k_{1}$, $\left(k_{2}+k_{3}\right)$, and $k_{4}$. The rate constants are estimated by a computerized, nonlinear, least squares fitting routine. 'The mean values \pm SEM of the rate constants obtained by this method for 17 gray matter regions were $0.082 \pm 0.004,0.151 \pm 0.008$, and $0.049 \pm 0.002$ for $k_{1},\left(k_{2}+k_{3}\right)$, and $k_{4}$, respectively.

Procedure. The animals were prepared for the determination of local rates of protein synthesis by the insertion under light halothane anesthesia of polyethylene catheters into one femoral vein and artery. The rat's hindquarters were then restrained by the application of a loosefitting plaster cast which was taped to a lead brick. After a period of 2 to $3 \mathrm{hr}$ for recovery from the effects of anesthesia, the procedure was initiated by the administration of an intravenous pulse of $L-\left[1-{ }^{14} \mathrm{C}\right]$ leucine (specific activity $59 \mathrm{mCi} / \mathrm{mmol}$; Amersham Corp., Arlington Heights, IL); the dose was $100 \mu \mathrm{Ci} / \mathrm{kg}$ of body weight contained in 0.1 to $0.4 \mathrm{ml}$ of physiological saline. Timed arterial blood samples were then collected during the following $60 \mathrm{~min}$ for the determination of plasma concentrations of leucine and $\left[{ }^{14} \mathrm{C}\right]$ leucine. The blood was immediately centrifuged to remove the red cells, and the plasma was stored on ice and assayed later. At the end of the 60-min experimental period the rats were killed by an intravenous injection of sodium pentobarbital, and the brains were quickly removed and frozen in isopentane cooled to $-40^{\circ} \mathrm{C}$ with dry ice. In nine experiments, the experimental period was limited to $30 \mathrm{~min}$ (see Table I), and the calculated rates were not significantly different from those obtained in the 60-min experiments. The brains were cut into sections $20 \mu \mathrm{m}$ in thickness in a cryostat maintained at $-18^{\circ} \mathrm{C}$, and the sections were dried on a hotplate at $60^{\circ} \mathrm{C}$ and autoradiographed along with calibrated $\left[{ }^{14} \mathrm{C}\right]$ methylmethacrylate standards as previously described (Sokoloff et al., 1977). Integrated optical densities of regions of the autoradiographs corresponding to selected brain structures were measured with a Photoscan System P-1000 densitometer (Optronics International, Inc., Chelmsford, MA) as previously described (Goochee et al., 1980). The structures were localized on the autoradiographs by comparison with the corresponding cresyl violet-stained sections. These optical densities were used to determine the local tissue concentrations of ${ }^{14} \mathrm{C}$ by comparison with the optical densities produced by the calibrated standards. The plasma samples were deproteinized with $4 \%$ sulfosalicyclic acid, and $\left[{ }^{14} \mathrm{C}\right]$ leucine and leucine concentrations were assayed by liquid scintillation counting and by amino acid analysis (Beckman Amino Acid Analyzer, model $121 \mathrm{MB}$, Beckman Instruments, Fullerton, CA), respectively. It is necessary to deproteinize the plasma samples because a significant amount of $\left[{ }^{14} \mathrm{C}\right]$ leucine is incorporated into plasma protein. From the time courses of the concentrations of $\left[{ }^{14} \mathrm{C}\right]$ leucine and leucine in the deproteinized plasma and the local tissue concentration of ${ }^{14} \mathrm{C}$, local rates of protein synthesis were calculated by means of the operational equation (Fig. $1 B$ ). Calculations were carried out with a Hewlett-Packard System 9845B computer (Hewlett Packard, Loveland, CO).

\section{Determination of regional rates of glucose utilization}

Rates of local cerebral glucose consumption were determined by means of the quantitative autoradiographic deoxyglucose method (Sokoloff et al., 1977). The animals were prepared in a manner similar to that described above for the measurement of protein synthesis. The procedure was initiated by the administration of an intravenous pulse of 2-deoxy-D- $\left[1{ }^{14} \mathrm{C}\right]$ glucose $(51 \mathrm{mCi} / \mathrm{mmol}$, New England Nuclear, Boston, MA); the dose was $125 \mu \mathrm{Ci} / \mathrm{kg}$ of body weight. Timed arterial blood samples were collected during the following $45 \mathrm{~min}$, and the plasma was separated by centrifugation. Determination of plasma concentrations of $\left[{ }^{14} \mathrm{C}\right]$ deoxyglucose and glucose were carried out by liquid scintillation counting and by means of a Beckman Glucose Analyzer (Beckman Instruments), respectively. After $45 \mathrm{~min}$, the animals were killed, and the brains were prepared for quantitative autoradiography as described above for the protein synthesis method. From the time courses of the concentrations of $\left[{ }^{14} \mathrm{C}\right]$ deoxyglucose and glucose in the plasma and the local tissue concentrations of ${ }^{14} \mathrm{C}$, local rates of glucose utilization were calculated by means of the operational equation of the method (Sokoloff et al., 1977).

\section{Image-processing of autoradiographs}

Both $\left[{ }^{14} \mathrm{C}\right]$ leucine and $\left[{ }^{14} \mathrm{C}\right]$ deoxyglucose autoradiographs were transformed into quantitative color-coded maps of the distribution of the local rates of protein synthesis or of glucose utilization by means of a 
A

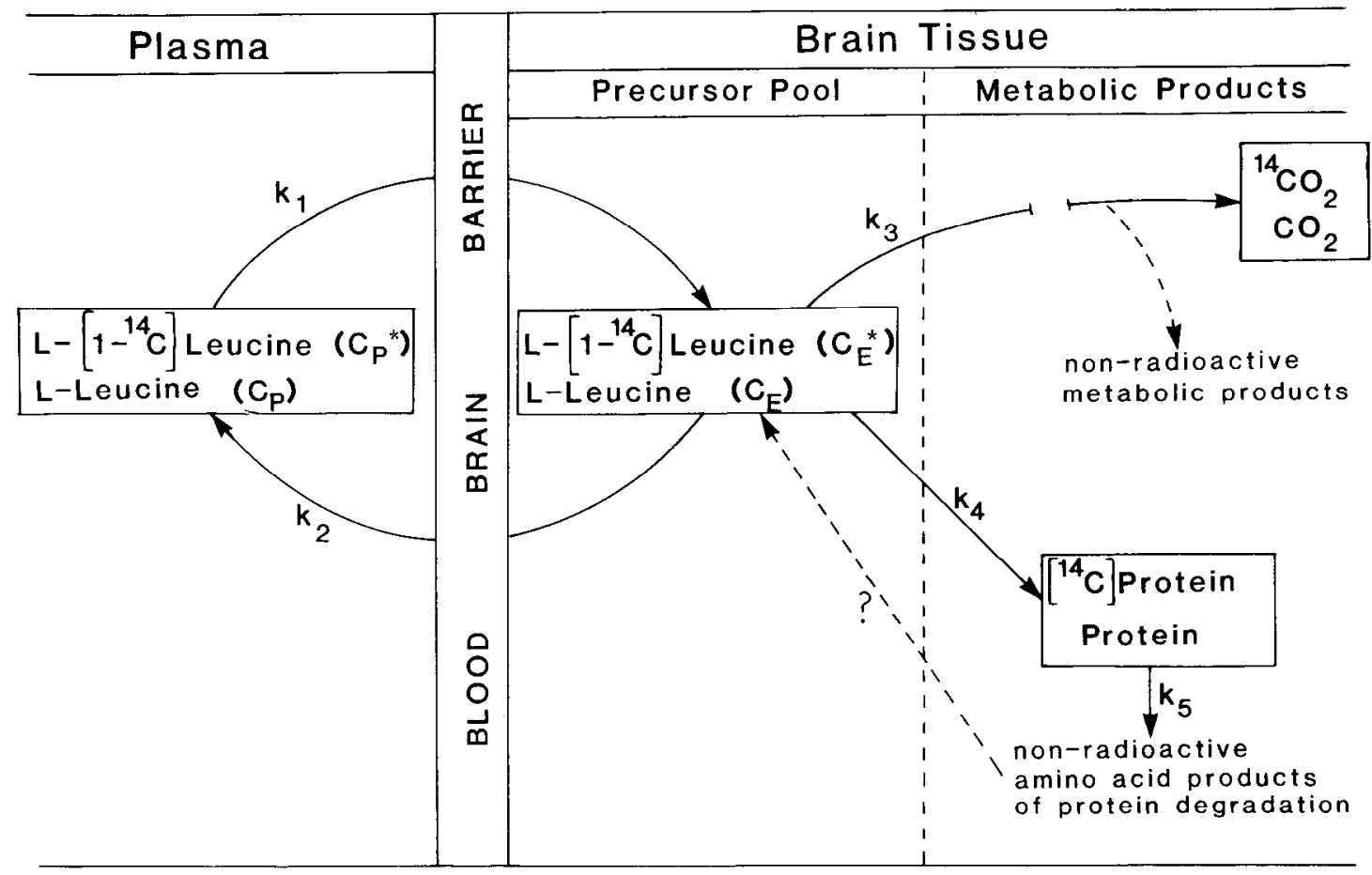

\section{B Operational Equation}

$$
v_{i}=\frac{C_{i}^{*}(T)-k_{1} e^{-\left(k_{2}+k_{3}+k_{4}\right) T} \int_{0}^{T} C_{p}^{*} e^{\left(k_{2}+k_{3}+k_{4}\right) t} d t}{\int_{0}^{T}\left(\frac{C_{p}^{*}}{C_{P}}\right) d t-e^{-\left(k_{2}+k_{3}+k_{4}\right) T} \int_{0}^{T}\left(\frac{C_{p}^{*}}{C_{P}}\right) e^{\left(k_{2}+k_{3}+k_{4}\right) t} d t}
$$

Figure 1. A, Diagrammatic representation of the theoretical model for the method of measurement of leucine incorporation into protein in brain. $C_{P}$ and $C_{P}^{*}$ represent the concentrations of free leucine and $\left[1{ }^{14} \mathrm{C}\right]$ leucine, respectively, in the arterial plasma; $C_{E}$ and $C_{E}^{*}$ represent the concentrations of free leucine and $\left[1{ }^{14} \mathrm{C}\right]$ leucine, respectively, in the tissue precursor pool for protein synthesis. The constants $k_{1}, k_{2}, k_{3}, k_{4}$, and $k_{5}$ represent the rate constants for carrier-mediated transport of leucine from plasma to tissue, for carrier-mediated transport back from tissue to plasma, for metabolic degradation of leucine, for incorporation of leucine into protein, and for degradation of protein to yield free leucine, respectively. The dashed arrow represents the possibility that the unlabeled leucine derived from protein degradation may dilute the precursor pool for protein synthesis. $B$, Operational equation of $\left[1{ }^{14} \mathrm{C}\right]$ leucine method. $C_{i}^{*}$ represents the total ${ }^{14} \mathrm{C}$ concentration in a single homogeneous tissue of the brain. $T$ represents the time at the termination of the experimental period. The other symbols are the same as those defined: $A$.

computerized image-processing system (Goochee et al., 1980). The autoradiographs were digitized, and the tissue concentrations in each spot were converted to rates of protein synthesis or glucose utilization by solution of the operational equation of each method. Colors were assigned to narrow ranges of the rates of either glucose utilization or protein synthesis, and the autoradiographs were reconstructed and displayed in color on a television monitor. The color bar displayed along with the reconstructed autoradiographic image provides the color calibration scale for identifying from its color the rate of protein synthesis or glucose utilization in each spot on the autoradiograph (Fig. 2).

\section{Assessment of functional recovery of the hypoglossal nerve}

Functional recovery of the hypoglossal nerve was assessed in another group of unilaterally axotomized rats by comparison of the twitch tension developed in the tongue during electrical stimulation of the control and the sectioned hypoglossal nerves proximal to the level of section. Nerves were stimulated via a constant current stimulus isolation unit with monopolar pulses of $1 \mathrm{msec}$ duration and $200 \mu \mathrm{A}$ current intensity at $2 \mathrm{~Hz}$. This current intensity was determined to be supra- maximal. Twitch tension in the tongue was measured by means of a force-displacement transducer.

\section{Results}

Effects of axotomy on protein synthesis and glucose utilization

Unilateral section of the hypoglossal nerve resulted in timedependent increases in the rates of both protein synthesis and glucose utilization in the hypoglossal nucleus ipsilateral to the cut (Table I, Figs. 2 and 3). The specifics of the time courses of these changes will be discussed below. These changes were found only in the hypoglossal nucleus (Fig. 2). The nucleus of the tractus solitarius, for example, which was also examined in these experiments, showed no changes following hypoglossal axotomy. In a group of 10 rats studied 2 to 24 days postaxolomy the mean values \pm SEM obtained for leucine incorporation into protein in the nucleus of the tractus solitarius, ipsilateral and contralateral to the cut side, were $5.8 \pm 0.4$ and $5.7 \pm 0.4$ $\mathrm{nmol} / \mathrm{gm} / \mathrm{min}$, respectively. Similarly, in a group of six rats 


\section{TABLE I}

Effects of unilateral axotomy on the rates of protein synthesis and glucose utilization in the hypoglossal nucleus

The data were obtained from 63 individual rats which were subjected to either the $\left[1-{ }^{14} \mathrm{C}\right]$ leucine method for the determination of local rates of protein synthesis or the $\left[{ }^{14} \mathrm{C}\right]$ deoxyglucose method for the determination of local rates of glucose utilization.

\begin{tabular}{|c|c|c|c|c|c|}
\hline \multirow{2}{*}{$\begin{array}{l}\text { Time after } \\
\text { Axotomy }\end{array}$} & \multirow{2}{*}{ Condition } & \multicolumn{2}{|c|}{ Protein Synthesis } & \multicolumn{2}{|c|}{ Glucose Utilization } \\
\hline & & Contralateral & Operated & Contralateral & Operated \\
\hline & & \multicolumn{2}{|c|}{$\mathrm{nmol}$ of leucine $/ \mathrm{gm} / \mathrm{min}$} & \multicolumn{2}{|c|}{$\mu \mathrm{mol} / 100 \mathrm{gm} / \mathrm{min}$} \\
\hline \multirow{3}{*}{$30 \mathrm{~min}$} & Sham-Op ${ }^{a}$ & 7.5 & 7.5 & & \\
\hline & Rt. Axot. ${ }^{b}$ & 6.4 & 6.3 & 46 & 47 \\
\hline & Rt. Axot. & 7.1 & 7.1 & 48 & 48 \\
\hline \multirow[t]{3}{*}{$3 \mathrm{hr}$} & Sham-Op & 6.3 & 6.5 & 48 & 50 \\
\hline & Rt. Axot. & 7.2 & 7.3 & 54 & 55 \\
\hline & Rt. Axot. & 7.6 & 7.4 & 51 & 51 \\
\hline \multirow[t]{3}{*}{$8 \mathrm{hr}$} & Sham-Op $p^{c}$ & 6.6 & 6.5 & 35 & 35 \\
\hline & Rt. Axot. ${ }^{c}$ & 7.2 & 7.2 & 48 & 49 \\
\hline & Rt. Axot. ${ }^{c}$ & 7.2 & 7.3 & 52 & 53 \\
\hline \multirow[t]{7}{*}{$24 \mathrm{hr}$} & Sham-Op & 6.5 & 6.5 & 41 & 42 \\
\hline & Left Axot. & 5.5 & 5.6 & & \\
\hline & Left Axot. & 6.2 & 6.2 & & \\
\hline & Rt. Axot. & 6.2 & 6.7 & 45 & 57 \\
\hline & Rt. Axot. & 7.0 & 7.6 & 55 & 63 \\
\hline & Rt. Axot. & & & 54 & 62 \\
\hline & Rt. Axot. & & & 60 & 69 \\
\hline \multirow[t]{3}{*}{2 days } & Sham-Op & & & & \\
\hline & Rt. Axot. & 5.6 & 7.1 & & \\
\hline & Rt. Axot. & 6.4 & 8.0 & & \\
\hline \multirow[t]{2}{*}{3 days } & Sham-Op & & & 51 & 49 \\
\hline & Rt. Axot. & & & 45 & 83 \\
\hline \multirow[t]{3}{*}{4 days } & Sham-Op & 7.0 & 6.8 & & \\
\hline & Rt. Axot. & 8.2 & 10.1 & & \\
\hline & Rt. Axot. & 9.7 & 11.1 & & \\
\hline \multirow[t]{3}{*}{10 days } & Sham-Op & & & 53 & 53 \\
\hline & Rt. Axot. & & & 56 & 89 \\
\hline & Rt. Axot. & & & 58 & 95 \\
\hline \multirow[t]{3}{*}{11 days } & Sham-Op & 5.6 & 5.4 & & \\
\hline & Rt. Axot. & 8.8 & 10.3 & & \\
\hline & Rt. Axot. & 7.0 & 8.5 & & \\
\hline 18 days & Sham-Op & 7.9 & 7.9 & 58 & 59 \\
\hline \multirow[t]{2}{*}{24 days } & Rt. Axot. ${ }^{c}$ & 7.3 & 9.2 & 45 & 75 \\
\hline & Rt. Axot.. & 6.5 & 8.7 & 48 & 63 \\
\hline \multirow[t]{3}{*}{35 days } & Sham-Op ${ }^{c}$ & 5.4 & 5.4 & 66 & 67 \\
\hline & Rt. Axot.c & 7.6 & 7.8 & 54 & 57 \\
\hline & Rt. Axot.c & 6.4 & 5.7 & & \\
\hline \multirow[t]{3}{*}{60 days } & Sham-Op & 6.0 & 5.9 & 46 & 46 \\
\hline & Rt. Axot. & 5.2 & 5.3 & 36 & 35 \\
\hline & Rt. Axot. & 4.3 & 4.1 & 44 & 45 \\
\hline \multirow[t]{3}{*}{84 days } & Sham-Op & 5.2 & 5.0 & 33 & 33 \\
\hline & Rt. Axot. & 5.5 & 5.2 & 45 & 44 \\
\hline & Rt. Axot. & 6.0 & 6.5 & 44 & 46 \\
\hline
\end{tabular}

${ }^{a}$ Sham-Op, sham operation.

${ }^{b}$ Rt. Axot., right axotomy.

${ }^{c}$ Protein synthesis experiments of 30 min duration.

studied 3 to 24 days postaxotomy the mean values \pm SEM obtained for glucose utilization in the nucleus of the tractus solitarius, ipsilateral and contralateral to the cut side, were 52 \pm 3 and $52 \pm 3 \mu \mathrm{mol} / 100 \mathrm{gm} / \mathrm{min}$, respectively.

There was no effect of sham operation on either protein synthesis or glucose utilization in either the hypoglossal nucleus
(Table I, Fig. 3) or the nucleus of the tractus solitarius ipsilateral to the operated side. In a group of three sham-operated rats the mean values \pm SEM obtained for protein synthesis in the nucleus of the tractus solitarius, ipsilateral and contralateral to the sham-operated side, were $5.6 \pm 0.2$ and $5.6 \pm 02$ $\mathrm{nmol} / \mathrm{gm} / \mathrm{min}$, respectively. Similarly, in another group of three sham-operated rats the mean values \pm SEM obtained for glucose utilization in the nucleus of the tractus solitarius were $57 \pm 1$ and $56 \pm 2$ ipsilateral and contralateral to the shamoperated side, respectively. There was also no apparent effect of axotomy on either the rate of protein synthesis or glucose utilization of the hypoglossal nucleus contralateral to the cut when compared with sham-operated controls (Table I).

Time courses of metabolic changes. The time courses of the effects on protein synthesis and glucose utilization in the hypoglossal nucleus were determined between $30 \mathrm{~min}$ and 12 weeks post-axotomy (Fig. 3). The earliest changes in glucose utilization occurred at $24 \mathrm{hr}$. By postaxotomy day 3 there was an $84 \%$ increase in glucose utilization over that of the control side. Glucose utilization remained elevated through day 24 and returned close to normal by day 35 . Protein synthesis may have increased slightly at $24 \mathrm{hr}$; i.e., of the four animals examined, two were increased 8 to $9 \%$ and two were unchanged. By postaxotomy day 2, protein synthesis had increased about $26 \%$ over the control side. Like glucose utilization, protein synthesis also remained elevated through postaxotomy day 24 and returned to normal or somewhat below normal levels by day 35 . From postaxotomy day 35 through 12 weeks the rates of both protein synthesis and glucose utilization were normal.

Time course of functional recovery. The degree of recovery of functional connections between the cut hypoglossal nerve and the tongue was evaluated between postaxotomy day 7 and 6 months (Fig. 3). Some functional recovery was noted at 20 days postaxotomy, and at 21 days the twitch tension in the tongue produced by stimulation of the cut side was half that produced by stimulation of the contralateral side. Animals examined through 6 months postaxotomy showed no further improvement. The stimulation threshold required to produce a tongue twitch was higher for the cut side compared to the control at all times examined, and the axotomized nerve fatigued faster than the control in every case.

\section{Discussion}

These studies show the temporal relationships of biochemical and functional changes which occur during axonal regeneration. Following unilateral hypoglossal axotomy there are increases in the rates of both glucose utilization and protein synthesis in the hypoglossal nucleus ipsilateral to the cut side. These changes follow a specific time course (Fig. 3). The increase in glucose utilization is greater than the increase in protein synthesis and may even precede the increase in protein synthesis by as much as $24 \mathrm{hr}$. The time courses of these changes have been compared with the time course of the recovery of a functional connection between the hypoglossal nerve and the tongue (Fig. 3).

Both the timing and the extent of the recovery of function were somewhat unexpected. The recovery occurred quite abruptly between postaxotomy day 19 and day 21 . On day 19 there was no measurable functional connection, whereas on day 21 it appeared to be completed. On day 21 the response reached half that of the contralateral control side, and through 6 months postaxotomy it did not improve further. The severity of the lesion may have determined to some extent the degree of recovery. This is suggested by an experiment in which a cold-crush lesion was imposed; the response on the lesioned side in this instance was identical to that of the control side on postaxotomy day 24.

Despite the recovery of functional efferent connections on 

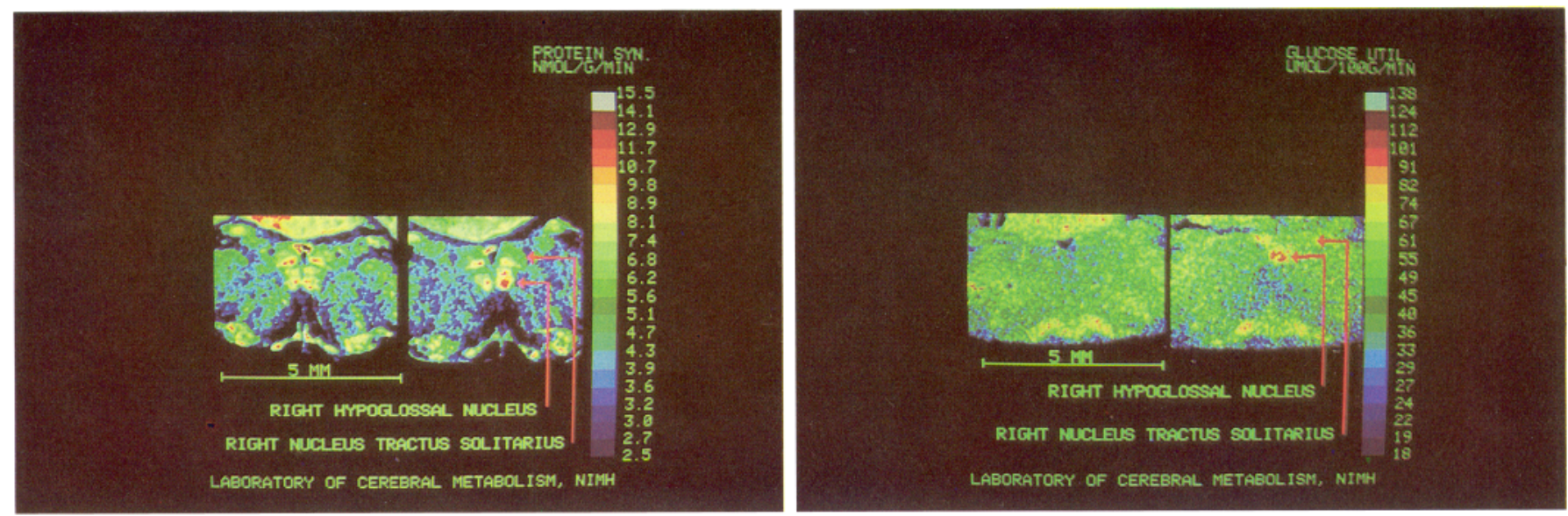

Figure 2. A, Quantitative color-coded transforms of $\left[1-{ }^{14} \mathrm{C}\right]$ leucine autoradiographs of brain sections at the level of the hypoglossal nucleus. Determinations of local rates of protein synthesis were carried out 11 days after surgery. The autoradiograph on the left is from a right shamoperated rat. The autoradiograph on the right is from a rat with right hypoglossal axotomy. The rates of protein synthesis are quantitatively encoded in color according to the accompanying calibration scale. $B$, Quantitative color-coded transforms of $\left[{ }^{14} \mathrm{C}\right]$ deoxyglucose autoradiographs of brain sections at the level of the hypoglossal nucleus. Determinations of local rates of glucose utilization were carried out 3 days after surgery. The autoradiograph on the left is from a right sham-operated rat. The autoradiograph on the right is from a rat following right hypoglossal axotomy. The absolute rates of glucose utilization are encoded in color according to the accompanying calibration scale.

postaxotomy day 21 , the rates of glucose utilization and protein synthesis in the axotomized hypoglossal nucleus remained elevated through postaxotomy day 24 . Although these data do not describe the day-by-day time course of the return to normal rates of both protein synthesis and glucose utilization, they suffice to show that restoration to normal follows the return of maximal function by at least 4 and by as much as 14 days. The continued high rates of protein synthesis and glucose utilization following a return of the functional innervation of the tongue are of interest in view of the observation that afferent synapses are reformed only after the efferent synapses are in place (Sumner, 1975; Rotter et al., 1979). That injured neurons become partially deafferented has been shown in a number of studies of hypoglossal axotomy in the rat (Sumner and Sutherland, 1973; Sumner, 1975; Rotter et al., 1979). The time courses of these synaptic changes in the axotomized hypoglossal nucleus are of particular interest in the light of the time course of the metabolic changes found in the present studies. These time courses may not be strictly comparable with the anatomical observations because of differences in sex of the experimental animals and in the level of axotomy, both of which may affect the rate of regeneration (Singer et al., 1982; Yu, 1982). The sequence of events, however, should be the same. Two days after axotomy muscarinic receptors are lost and continue to decrease to about $50 \%$ of control by day 5 (Rotter et al., 1979). The number of synapses on the hypoglossal neurons also decreases (Sumner, 1975; Rotter et al., 1979). Dendritic boutons decrease linearly to about $50 \%$ of control over the first 35 days, whereas somatic boutons decrease more rapidly in the first 7 days postaxotomy and are practically nonexistent through day 35 (Sumner, 1975). Dendrites shrink and some degenerate (Sumner and Sutherland, 1973). Following reinnervation of the tongue all of these indices of synaptic integrity return to normal. Specifically, muscarinic receptors achieve control levels between 40 and 60 days postaxotomy (Rotter et al., 1979). The numbers of somatic and dendritic boutons return to normal levels by postaxotomy day 49 (Sumner, 1975). The metabolic state of the hypoglossal cells as assessed in the present studies may be biphasic with the initial response reflecting regeneration of the injured hypoglossal axons, and the second phase reflecting repair and re-formation of afferent synaptic junctions. Each of these processes would require an increase in protein synthesis.
The present studies to determine local rates of protein synthesis in the brain utilize a simplified version of a more elaborate quantitative autoradiographic method (Smith et al., 1980) that is still under development. Details of development and validation of the complete method will be published separately. In the simplified version the kinetic model for the behavior of leucine in brain (Fig. 1) utilizes a single free leucine compartment in brain and assumes no admixture of leucine derived from protein degradation with the precursor pool for protein synthesis. While this model is probably oversimplified, it is adequate for the present studies for the following reasons. There are two major requirements for a method of this type: (1) a means of determining the amount of product formed (the numerator of the operational equation (Fig. $1 B)$ ), and (2) a means of determining the integrated specific activity of the precursor pool for the reaction (the denominator of the operational equation (Fig. $1 B$ )). The total amount of ${ }^{14} \mathrm{C}$ in the tissue at the end of the experiment, $C_{i}^{*}$, is determined by quantitative autoradiography; it represents the combined concentrations of $\left[{ }^{14} \mathrm{C}\right]$ leucine incorporated into protein (i.e., product) and residual free $\left[{ }^{14} \mathrm{C}\right]$ leucine remaining in the precursor pool. The amount of product formed is calculated from the total amount of ${ }^{14} \mathrm{C}$ in the tissue by subtraction of the free $\left[{ }^{14} \mathrm{C}\right]$ leucine concentration in the tissue represented by the second term in the numerator. As calculated with the equation, this second term equals only 2 to $5 \%$ of the $C_{i}^{*}$ at $60 \mathrm{~min}$ after the pulse. Also, acid-soluble ${ }^{14} \mathrm{C}$, which includes free $\left[{ }^{14} \mathrm{C}\right]$ leucine and $\alpha$ $\left[{ }^{14} \mathrm{C}\right]$ ketoisocaproic acid, if any, has been experimentally measured and found to be approximately $5 \%$ of the $C_{i}^{*} 60 \mathrm{~min}$ after the pulse of $\left[1-{ }^{14} \mathrm{C}\right]$ leucine. The correction of $C_{i}^{*}$ for free $\left[{ }^{14} \mathrm{C}\right]$ leucine is, therefore, so small a source of error that it was considered adequate to compute the correction rather than to remove the free leucine pool by experimental means before the autoradiography. The integrated specific activity of the precursor pool is calculated from the history of the plasma specific activity (first term in denominator) and the lag between the plasma and the precursor pool in the tissue (second term in denominator). The half-life of the precursor pool has been estimated in a separate series of experiments to be less than $3.5 \mathrm{~min}$. With a pool turning over at such a rapid rate, the difference between its integrated specific activity and that of the plasma will be relatively small 30 to $60 \mathrm{~min}$ after a pulse of $\left[{ }^{14} \mathrm{C}\right]$ leucine, and correction for the lag is almost negligible. 


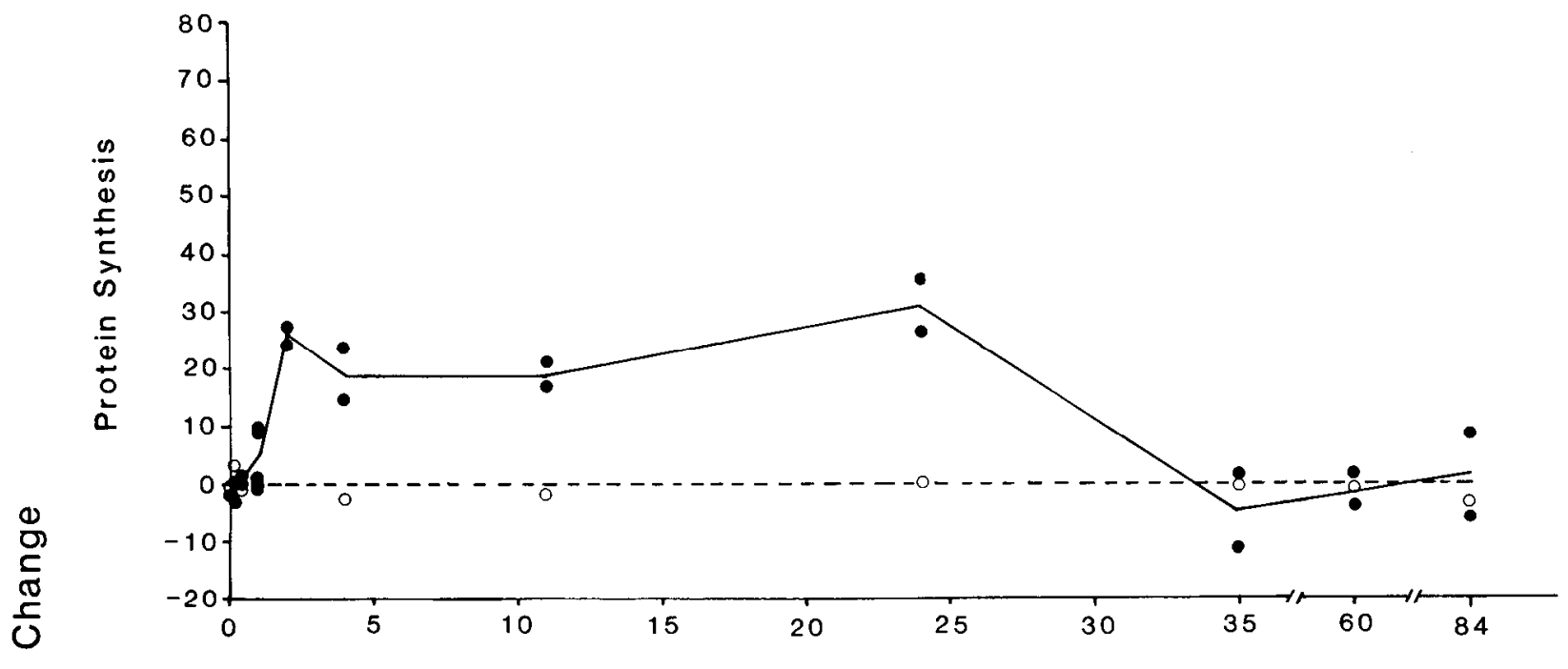

든
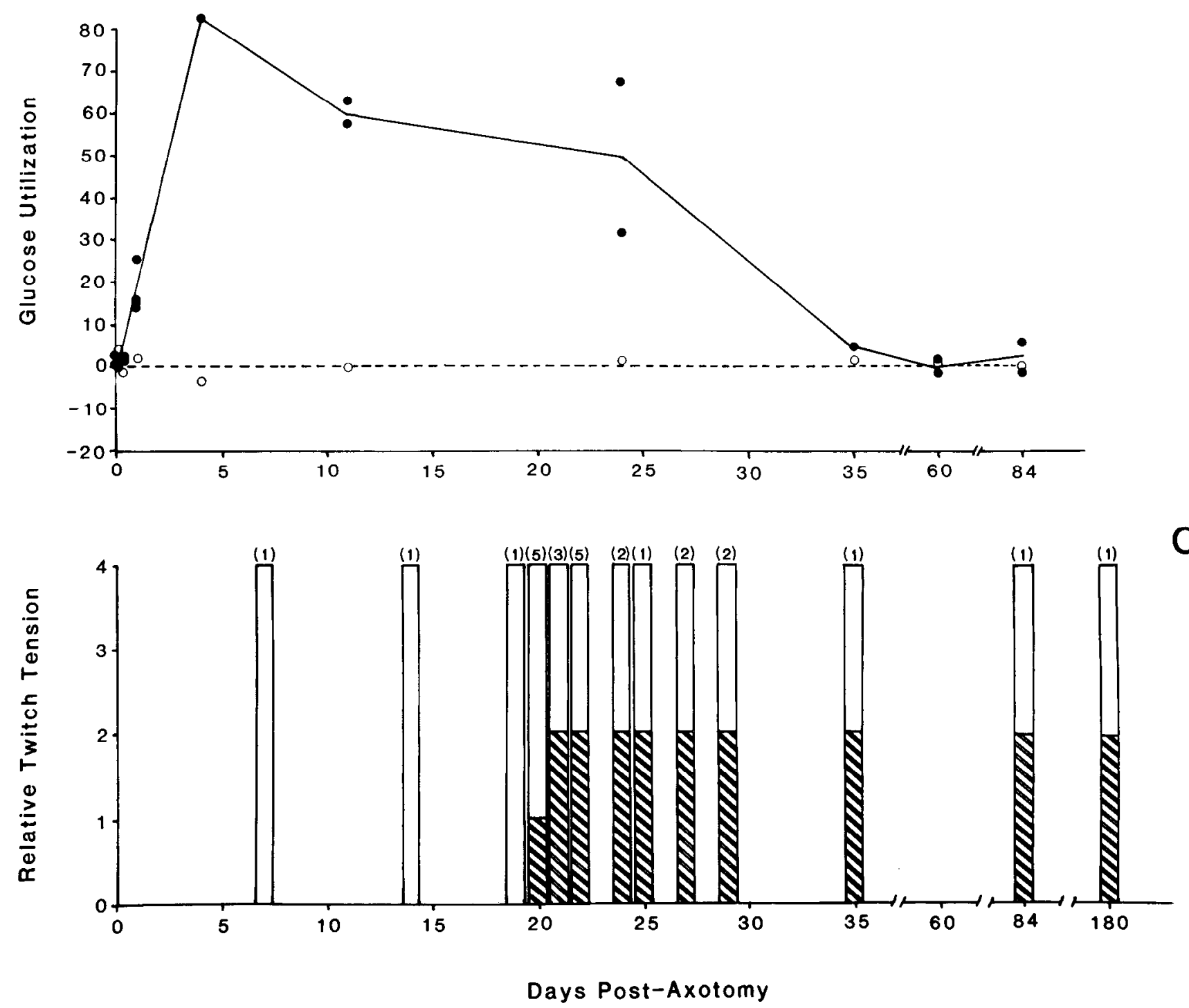

Figure 3. Time courses of the changes in rates of protein synthesis $(A)$ and glucose utilization $(B)$ in the ipsilateral hypoglossal nucleus as a percentage of the corresponding rates in the contralateral (control) nucleus. Each point represents a value in a single rat. The solid circles represent values from axotomized animals, and the open circles represent values from sham-operated animals. The lines have been drawn through the mean values at each time point. $C$, The time course of the return of functional innervation of the tongue following unilateral hypoglossal axotomy. The twitch tension in the tongue elicited by electrical stimulation of a hypoglossal nerve was rated $0,1,2,3$, or 4 , with 4 assigned to the tension achieved by stimulation of the control nerve. The open bars represent the mean response of the tongue to supramaximal electrical stimulation of the hypoglossal nerve contralateral to the axotomy. The cross-hatched bars represent the mean response of the tongue to stimulation of the previously axotomized hypoglossal nerve. The number in parentheses above each set of bars is the number of animals in each group. 
The assumption that there is no admixture of leucine derived from protein degradation with the precursor pool is one for which there is only evidence derived from in vitro experiments (Gainer et al., 1975; Robertson and Wheatley, 1979). Such admixture would complicate the determination of the integrated precursor pool specific activity (the denominator of the operational equation (Fig. 1B)) because it would provide a source of constant dilution of the radioactive amino acid entering the precursor pool from the plasma. Experiments are currently in progress which may assess the degree of admixture, but, in the meantime, the rates of protein synthesis in the present studies were calculated with the assumption that the admixture is negligible. If there is indeed significant admixture, then the data presented here represent only the minimal rates of leucine incorporation into protein. The increased $\left[{ }^{14} \mathrm{C}\right]$ leucine incorporation into protein in regenerating hypoglossal nuclei might then reflect a decreased dilution of the precursor amino acid pool because of a decrease in the rate of protein degradation. This is unlikely in view of the results of a number of other studies which suggest that protein synthesis is, in fact, increased. RNA synthesis and turnover are increased following axotomy (Watson 1965, 1968, 1970; Burrell et al., 1978), and these are changes consistent with increased protein synthesis.

These experiments were designed to determine the time course and the magnitude of biochemical changes that occur following axotomy. For these purposes the simplified method for the determination of local rates of protein synthesis is adequate. At best the method is accurate as it is described here, and the absolute rates of leucine incorporation into protein are correct. The worst possibility is that the precursor pool specific activity has been overestimated, and the rates reported here are minimal rates. For the purposes of these present studies even minimal rates will describe both the magnitude and the time course of the changes in protein synthesis that occur during regeneration.

Evidence of increased rates of glucose utilization in the nuclei of axotomized nerves has been reported previously (Agranoff et al., 1980; Kreutzberg and Emmert, 1980; Singer and Mehler, 1980). The present studies provide quantitative estimates of the magnitude of the effect and its time course. The increase is large, as much as $84 \%$ over control values. What cellular processes are responsible for this increased netabolic activity is a question of some interest. The energy requirements for the relatively small increase in protein synthesis are much too small to account for the increase in glucose utilization. Another possibility is that the membrane properties of regenerating neurons are changed (Watson, 1974). If the membranes were to become leaky or if the sodium pump became inefficient, more energy would be required to fuel the sodium pump. Electrophysiological studies have shown that axotomized motor neurons have lowered thresholds for the generation of spikes in the soma-dendritic membrane (Kuno and Llinás, 1970; Takata et al., 1980). Even regenerating cells with normal resting membrane potentials (Eccles et al., 1958) may undergo spontaneous firing (Takata et al., 1980).

It is important to note that in the present studies the measurements of protein synthesis and glucose utilization apply to the hypoglossal nucleus as a whole. Which individual cell types show the changes cannot be determined from the low resolution autoradiographs (Fig. 2). Morphological studies have shown that microglia, oligodendrocytes, and astrocytes within the hypoglossal nucleus all react after axotomy. Microglia divide near reacting neurons after axotomy (Watson, 1965). The proliferation of microglia occurs by postaxotomy day 8 ; by day 30 the number of microglia returns to normal (Watson, 1965). The proliferation of these cells correlates with the loss of presynaptic boutons. The microglia are of brain parenchymal origin, and there is no evidence for infiltrating cells. The role of microglia in the process of regeneration is unclear, and it is possible that they could be contributing to the metabolic changes found in these studies.

Astrocytes become hypertrophic both when the boutons are removed from the injured neuron and again when they are restored between postaxotomy days 20 and 80 (Watson, 1972). The astrocytic processes are in close contact with the surface of the neuron both before and after removal of boutons (Watson, 1972). Hypertrophic astrocytes are also reported in the contralateral hypoglossal nucleus shortly after axotomy (Watson, 1972). Because these astrocytic changes are found in both ipsilateral and contralateral nuclei, it is unlikely that they can fully account for either of the metabolic changes described in this study.

Myelinating oligodendrocytes become hypertrophic only when the boutons are reconnected to the neuron (Watson, 1972); this response may be a function of the maturation of the terminal fibers. The hypertrophy of oligodendrocytes occurs at a time when the protein synthesis and glucose utilization responses are waning and is, therefore, not the significant event regulating these metabolic responses.

Therefore, the neurons of the regenerating hypoglossal and nucleus appear to be the best candidates for the metabolic changes found in these studies. The temporal correspondence between the morphological changes seen in neurons of the hypoglossal nucleus following axotomy and the metabolic changes found in these studies is excellent. The initial increases in protein synthesis and glucose utilization found in the first 2 days postaxotomy correlate with the swollen appearance of the injured neurons and the dispersion of aggregated ribosomes. This early phase of the protein synthetic response probably reflects the initial effort to regenerate and continues through the restoration of a functional connection on day 21. Protein synthesis remains elevated even after this connection is complete and does not return to normal levels until the neurons are at least partially reafferented. The increase in glucose utilization parallels that of protein synthesis and exceeds the energy requirement of the increased protein synthesis. The reason for so great an increase in energy metabolism in regenerating neurons is unclear, but it may reflect changes in excitability in the soma-dendritic membrane which presumably return to normal when the cells are reafferented.

\section{References}

Agranoff, B. W., C. B. Smith, and L. Sokoloff (1980) Regional protein synthesis in rat brain after hypoglossal axotomy. Trans. Am. Soc. Neurochem. 11: 95.

Banker, G., and C. W. Cotman (1971) Characteristics of different amino acids as protein precursors in mouse brain: Advantages of certain carboxyl-labeled amino acids. Arch. Biochem. Biophys. 142: $565-573$.

Brattgard, S. -O., H. Hyden, and J. Sjöstrand (1958) Incorporation of orotic acid ${ }^{14} \mathrm{C}$ and lysine $-{ }^{-14} \mathrm{C}$ in regenerating single nerve cells. Nature 182: 801-802.

Burrell, H. R., L. A. Dokas, and B. W. Agranoff (1978) RNA metabolism in the goldfish retina during optic nerve regeneration. J. Neurochem. 31: $289-298$.

Cheah, H., and L. B. Geffen (1973) Effects of axonal injury on norepinephrine, tyrosine hydroxylase and monoamine oxidase levels in sympathetic ganglia. J. Neurobiol. 4: 443-452.

Eccles, J. C., B. Libet, and R. R. Young (1958) The behaviour of chromatolysed motoneurons studied by intracellular recording. J. Physiol. (Lond.) 143: 11-40.

Engh, C. A., B. H. Schofield, S. B. Doty, and R. A. Robinson (1971) Perikaryal synthetic function following reversible and irreversible peripheral axon injuries as shown by radioautography. J. Comp. Neurol.142: 465-480.

Gainer, H., J. L. Barker, and Z. Wollberg (1975) Preferential incorporation of extracellular amino acids into neuronal proteins. J. Neurochem. 25: 177-179.

Goochee, C., W. Rasband, and L. Sokoloff (1980) Computerized densitometry and color coding of $\left[{ }^{14} \mathrm{C}\right]$ deoxyglucose autoradiographs. Ann. Neurol. 7: 359 370 . 
Härkönen, M. H. A., and F. C. Kaufman (1974) Metabolic alterations in the axotomized superior cervical ganglion of the rat. II. The pentose phosphate pathway. Brain Res. 65: 141-157.

Heacock, A. M., and B. W. Agranoff (1976) Enhanced labeling of a retinal protein during regeneration of optic nerve in goldfish. Proc. Natl. Acad. Sci. U. S. A. 73: 828-832.

Hebb, C. O., and G. M. H. Waites (1956) Choline acetylase in anteroand retrograde degeneration of a cholinergic nerve. J. Physiol. (Lond.) 132: 667-671.

Kreutzberg, G. W., and H. Emmert (1980) Glucose utilization of motor nuclei during regeneration: $\mathrm{A}\left[{ }^{14} \mathrm{C}\right] 2$-deoxyglucose study. Exp. Neurol. 70: 712-716.

Kuno, M., and R. Llinás (1970) Enhancement of synaptic transmission by dendritic potentials in chromatolysed motoneurones of the cat. $J$. Physiol. (Lond.) 210: 807-821.

Lieberman, A. R. (1971) The axon reaction: A review of the principal features of perikaryal responses to axon injury. Int. Rev. Neurobiol. 14: $50-124$.

Murray, M. (1973) ${ }^{3} \mathrm{H}$-Uridine incorporation by regenerating retinal ganglion cells of goldfish. Exp. Neurol. 39: 489-497.

Nissl, F. (1892) Über die Veränderungers der Ganglienzellen am facialiskern des Kaninchens nach Ausreissung der Nerven. Allg. Z. Psychiatr. 48: 197-198.

Robertson, J. H., and D. N. Wheatley (1979) Pools and protein synthesis in mammalian cells. Biochem. J. 178: 699-709.

Rotter, A., N. J. M. Birdsall, A. S. V. Burgen, P. M. Field, A. Smolen, and G. Raisman (1979) Muscarinic receptors in the central nervous system of the rat. IV. A comparison of the effects of axotomy and deafferentation on the binding of $\left[{ }^{3} \mathrm{H}\right]$ propylbenzilylcholine mustard and associated synaptic changes in the hypoglossal and pontine nuclei. Brain Res. Rev. 1: 207-224.

Singer, P., and S. Mehler (1980) 2-Deoxy $\left({ }^{14} \mathrm{C} /\right.$ glucose uptake in the rat hypoglossal nucleus after nerve transection. Exp. Neurol. 69: 617626.

Singer, P. A., S. Mehler, and H. L. Fernandez (1982) Blockade of retrograde axonal transport delays the onset of metabolic and mor- phologic changes induced by axotomy. J. Neurosci. 2: 1299-1306.

Smith, C. B., L. Davidsen, G. Deibler, C. Patlak, K. Pettigrew, and L. Sokoloff (1980) A method for the determination of local rates of protein synthesis in brain. Trans. Am. Soc. Neurochem. 11:94.

Sokoloff, L., M. Reivich, C. Kennedy, M. H. Des Rosiers, C. S. Patlack, K. D. Pettigrew, O. Sakurada, and M. Shinohara (1977) The $\left[{ }^{14} \mathrm{C}\right]$ deoxyglucose method for the measurement of local cerebral glucose utilization: Theory, procedure, and normal values in the conscious and anethetized albino rat. J. Neurochem. 28: 897-916.

Sumner, B. E. H. (1975) A quantitative analysis of the response of presynaptic boutons to postsynaptic motor neuron axotomy. Exp. Neurol. 46: 605-615.

Sumner, B. E. H., and F. I. Sutherland (1973) Quantitative electron microscopy on the injured hypoglossal nucleus in the rat. J. Neurocytol. 2: 315-328.

Takata, M., E. Shohara, and S. Fujita (1980) The excitability of hypoglossal motoneurons undergoing chromatolysis. Neuroscience 5 : 413-419.

Watson, W. E. (1965) An autoradiographic study of the incorporation of nucleic-acid precursors by neurones and glia during nerve regeneration. J. Physiol. (Lond.) 180: 741-753.

Watson, W. E. (1966) Quantitative observations upon acetylcholine hydrolase activity of nerve-cells after axotomy. J. Neurochem. 13: 1549-1550.

Watson, W. E. (1968) Observations on the nucleolar and total cell body nucleic acid of injured nerve cells. J. Physiol. (Lond.) 196: 655-676.

Watson, W. E. (1970) Some metabolic responses of axotomized neurones to contact between their axons and denervated muscle. J. Physiol. (Lond.) 210: 321-343.

Watson, W. E. (1972) Some quantitative observations upon the responses of neuroglial cells which follow axotomy of adjacent neurones. J. Physiol. (Lond.) 225: 415-435.

Watson, W. E. (1974) Cellular responses to axotomy and to related procedures. Br. Med. Bull. 30: 112-115.

Yu, W. - H. A. (1982) Sex difference in the regeneration of the hypoglossal nerve in rats. Brain Res. 238: 404-406. 